\title{
IMPLEMENTASI PRODUKSI PROGRAM ACARA “TEKNOTANI" DI LPP TVRI YOGYAKARTA
}

\author{
Susilawati $^{1}$, Ade Wahyudin ${ }^{2}$ \\ 1) 2) Program Studi Manajemen Teknik Studio Produksi, Sekolah Tinggi Multi Media Yogyakarta \\ Jl. Magelang No.KM.6, Mlati, Sleman, D. I. Yogyakarta 55284 \\ Email: susiedit@yahoo.com
}

\begin{abstract}
The TEKNOTANI program produced by TVRI Yogyakarta is still a mainstay broadcast program for farmers in the Yogyakarta region. As a mainstay broadcast program, TEKNOTANI is produced with collaboration outside the studio and inside the studio, where producers are concurrently acting as screenwriters, creative, and broadcast continuity personnel. The purpose of this study was to determine the production process of the TEKNOTANI program at LPP TVRI Yogyakarta. This research method uses a qualitative approach, which is a research procedure that produces descriptive data in the form of written or oral words and observed behavior from four sources. Data collection techniques in this study include interviews, observing certain behaviors, studying written documents, or checking visual images. The results achieved in this study include three stages, namely the pre-production stage begins with the search for program material that can be obtained from print media, electronic media, or from online media, as well as from the network of previous sources. Next, a field survey was conducted to find out whether or not the land would be filmed and coordinate with the resource person, who would be the resource person. At the production, the stage is the implementation of filming. In this TEKNOTANI program, filming is done in two stages, namely the shooting stage for visualization in the field as insert material during production in the studio and shooting in the studio. The results from shooting in the studio are already worthy results to be broadcast. In the post-production process is done to edit images and sounds that have been produced outside the studio or in the field. The editing process is done through two stages, namely offline editing, then online editing.
\end{abstract}

Keywords: TEKNOTANI, Television Program Production, TVRI, Agriculture.

\begin{abstract}
Abstrak: Program TEKNOTANI produksi TVRI Yogyakarta, masih menjadi siaran andalan bagi warga tani di wilayah Yogyakara. Sebagai program siaran andalan, TEKNOTANI diproduksi dengan kolaborasi di luar studio (outdoor) dan di dalam studio (indoor), dimana produser merangkap sebagai penulis naskah, tenaga kreatif serta tenaga kontinuitas siaran. Tujuan dari penelitian ini adalah untuk mengetahui proses produksi program TEKNOTANI di LPP TVRI Yogyakarta. Metode penelitian ini menggunakan pendekatan kualitatif, yaitu prosedur penelitian yang menghasilkan data deskriptif berupa kata-kata tertulis atau lisan dan perilaku yang teramati dari empat narasumber. Teknik pengumpulan data dalam penelitian ini meliputi wawancara, observasi perilaku tertentu, mempelajari dokumen tertulis, atau memeriksa visual image. Hasil yang di capai dalam penelitian ini meliputi tiga tahap, yaitu tahap pra-produksi diawali dengan pencarian materi program yang bisa didapatkan dari media cetak, media elektronik maupun dari media online, serta dari jaringan narasumber sebelumnya. Selanjutnya dilakukan survey di lapangan untuk mengetahui tepat tidaknya lahan yang akan di shooting serta melakukan koordinasi dengan narasumber, siapa saja yang akan dijadikan narasumber. Pada tahap produksi merupakan pelaksanaan shooting. Pada program TEKNOTANI ini shooting dilakukan dengan dua tahap yaitu tahap shooting untuk visualisasi di lapangan (outdoor) sebagai bahan insert saat produksi di studio serta shooting di studio (indoor). Hasil dari shooting di studio sudah merupakan hasil yang layak untuk disiarkan. Pada proses pasca produksi dilakukan untuk menyunting gambar dan suara yang telah diproduksi di luar studio atau di lapangan. Proses editing dilakukan melalui dua tahap yaitu editing offline, kemudian editing online.
\end{abstract}

Kata Kunci: TEKNOTANI, Produksi Acara Televisi, TVRI, Pertanian.

\section{PENDAHULUAN}

Daerah Istimewa Yogyakarta walaupun terkenal sebagai Kota pelajar dan pusatnya kaum intelekual, namun di sisi yang lain masih memiliki warga yang berprofesi sebagai petani. Pada tahun 2019, di Provinsi D.I Yogyakarta terdapat 111.477 Ha area lahan panen dan 62 ribu penduduk 
bekerja disektor pertanian (Yogyakarta, 2020). Sehingga sektor pertanian merupakan salah satu penopang perekonomian masyarakat, terutama diwilayah suburban dan rural.

Menyadari adanya segmentasi dari khalayak pemirsa dari kalangan masyarakat dibidang pertanian, maka LPP TVRI Yogyakara membuat program acara “TEKNOTANI". Program acara ini diharapkan mampu menjembatani kepentingan masyarakat tani. Selain itu, TEKNOTANI dapat menjadi sumber informasi masyarakat terhadap teknologi pertanian terbaru.

Sebagai salah satu program siaran andalan, produksi program acara TEKNOTANI dilaksanakan secara profesional dengan tim produksi yang berkompetensi. Selain itu, peran produser cukup penting dalam proses produksi program acara ini. Karena selain perperan sebagai penanggungjawab dan perencanaan, juga merangkap sebagai penulis naskah, tenaga kreatif serta tenaga kontinuitas siaran.

Proses produksi televisi merupakan sebuah proses pembuatan program yang nantinya ditayangkan di televisi dan memerlukan perjalanan panjang dan melewati berbagai tahapan, dan melibatkan banyak sumber daya manusia. Proses produksi program acara TEKNOTANI, secara umum sama seperti program televisi lainnya. Diawali dengan tahapan pra-produksi, dimana tim produksi melakukan riset dan survey terhadap tema yang akan di angkat. Selanjutnya, proses produksi dan pasca produksi lakukan dengan cukup rumit. Hal ini dikarenakan proses produksi dilakukan secara indoor maupun outdoor, sehingga selain diperlukan koordinasi yang baik juga kompetensi pengarah acara dan produser dalam merencanakan program acara ini.

Televisi berasas dari kata "tele" yang berarti jauh dan "visi" (vision) yang berarti penglihatan. Sedangkan secara lebih jelasnya, televisi merupakan media dari jaringan dengan ciri-ciri yang dimiliki komunikasi massa. Televisi merupakan penggabungan antara radio dan film. Sebab televisi dapat meneruskan suatu peristiwa dalam bentuk gambar yang begerak atau video dengan suara (Arifin et al., 2015). Orang yang duduk di depan pesawat televisi dirumahnya seringkali memperoleh pandangan yang lebih jelas daripada orang-orang yang hadir di tempat peristiwa sendiri. Dengan demikian televisi memiliki sifat aktualitas yang melebihi surat kabar dan radio (Luthfi, 2018).

Dibandingkan dengan media massa lainnya, televisi mempunyai sifat yang istimewa. Televisi merupakan gabungan dari media dengar atau suara dan gambar, bisa bersifat informatif, hiburan, maupun pendidikan, bahkan gabungan dari ketiga unsur diatas. Selain itu, televisi merupakan 
sumber citra dan pesan tersebar (shared images and message) yang sangat besar dalam sejarah, dan ini telah menjadi mainstream bagi lingkungan simbolik masyarakat (Wulandari \& Wahyudin, 2020). Selain itu, televisi merupakan sistem bercerita (story-telling) yang tersentralisasi. Saat ini Televisi telah menjadi bagian tidak terpisahkan dari kehidupan manusia. Banyak orang menghabiskan waktunya lebih lama di depan televisi (Kustanto, 2016).

Siaran televisi adalah pemancaran sinyal listrik yang membawa muatan gambar dan suara yang terbentuk pada sistem lensa dan suara. Menurut Peter Herford, setiap stasiun televisi dapat menayangkan beberapa acara hiburan seperti, film, musik, kuis, talk show atau dialog dan sebagainnya. Melalui karakter audio visual yang dimilikinya, media televisi memiliki daya tarik dan kekuatan khusus serta teknologinya berkembang pesat dan jangkauannya luas (Subroto, 1994).

Hal ini menjadi salah satu alasan yang mendorong masyarakat untuk memilih media televisi sebagai media sumber informasi dibandingkan dengan media massa lainnya. Masyarakat di daerah perkotaan dan pedesaan untuk saat ini mempunyai akses yang baik terhadap media televisi (Purwanto et al., 2019). Kawasan peri-urban merupakan kawasan yang sebagian masyarakatnya mempunyai televisi dan mengaksesnya pada saat waktu luang, Pada kawasan ini kehidupan pada bidang pertanian masih sangat kental dan berjalan berdampingan dengan kemajuan teknologi yang merupakan imbas dari modernisasi perkotaan (Afifi, 2010). Melihat siaran melalui media televisi sama seperti media massa yang lainnya yaitu sebagai media untuk menyampaikan pesan yang berupa informasi kepada khalayak, namun dalam hal ini televisi memiliki tiga fungsi pokok yaitu (Latief \& Utud, 2017): (1) Fungsi penerangan (the information function), Dalam hal ini televisi mendapatkan perhatian yang besar di kalangan masyarakat, karena dirasa media televisi dianggap sebagai media yang mampu menyiarakan sebuah informasi yang sangat memuaskan bagi pemirsa di rumah; (2) Fungsi pendidikan (the educational fuction), sebagai salah satu media massa yang dianggap ampuh dalam untuk menyiarkan sebuah program yang bertujuan untuk memberikan edukasi atau pendidikan kepada pemirsa di rumahnya berupa meningkatkan sebuah pengetahuan dan penalaran kepada masyarakat; (3) Fungsi Hiburan (The Entertainment Function), Televisi sebagai media hiburan, dalam fungsi ini sebenarnya sangat melekat pada media televisi, dan lebih dominan ketimbang dengan fungsi lainnya. Dimana melalui media televisi manusia cenderung mencari kesibukan atau hiburan 
setelah melakukan berbagai aktivitas seharian ini (Sunarsa et al., 2020).

Lebih jauh tentang televisi, (Morissan, 2008) menyatakan bahwa televisi memiliki beberapa karakteristik, sebagai beikut: (1) Audiovisual. Televisi memiliki kelebihan dalam hal audio visual, yang dapat memberikan gambar serta suara sekaligus dalam menyampaikan informasi; Berpikir dalam gambar. Ada dua tahap yang dilakukan dalam proses ini, Pertama adalah visualisasi, yaitu menterjemahkan kata-kata yang mengandung gagasan yang menjadi gambar-gambar, dan kedua adalah penggambaran, yakni kegiatan merangkai gambar-gambar individual sedemikian rupa sehingga kontinuitasnya mengandung makna tertentu; (3) Pengoprasian atau cara kerja yang kompleks. Pengoprasian atau cara kerja televisi lebih kompleks dibandingkan dengan media massa lainnya, karena dalam satu produksi televisi harus melibatkan banyak orang dan juga alat-alat teknis.

Untuk mewujudkan sebuah produksi televisi, dibutuhkan sebuah proses waktu yang tidak sesaat. Sebab suatu produksi audio video merupakan Kerja Tim Produksi, biaya yang besar dan banyak peralatan maka perlu pengorganisasian yang rapi dan perlu suatu tahapan produksi yang jelas (Fahruddin \& Asy’ari, 2019). Tahapan produksi terdiri dari tiga bagian yang lazim di industri televisi dikenal dengan istilah Standard Operation Procedure (SOP) yaitu: Pra-Produksi (Perencanaan), Produksi (Pelaksanaan), Pasca Produksi.

Program siaran secara keseluruhan dapat diartikan sebagai segmen atau satu bagian dari isi siaran radio ataupun televisi. Sehingga dapat memberi pengertian bahwa dalam siaran keseluruhan pada satu stasiun televisi terdapat beberapa program siaran yang ditayangkan (Kurniawati, 2019). Program siaran dapat dikatakan dalam siaran keseluruhan pada satu stasiun televisi tersusun dari berbagai program siaran. Untuk masing-masing program siaran ini menempati slot waktu yang sudah ditentukan dengan durasi tayang tertentu berdasarkan dari jenis programnya, program tersebut bisa program hiburan, program berita, dan program informasi. Masing-masing program, slot waktu akan dirancang sesuai dengan tema program itu sehingga menjadi jadwal siaran tiap harinya (N. Nasution, 2018).

Program talkshow atau program dialog menurut Fred Wibowo dalam bukunya Teknik Produksi Televisi (Wibowo, 2007), program talkshow adalah program pembicaraan tiga orang atau lebih mengenai suatu permasalahan. Dalam program ini masing-masing tokoh yang diundang dapat saling berbicara mengemukakan pendapat dan presenter 
bertindak sebagai moderator yang kadangkadang juga melontarkan pendapat atau membagi pembicaraan.

Untuk memberi gambaran tentang pelaksanan sebuah produksi program televisi, dibutuhkan sebuah kerabat kerja produksi, yang biasanya terdiri atas (Raharjo \& Anisti, 2018): (1) Produser, seseorang yang bertanggung jawab terhadap perencanaan suatu program siaran dan harus mempunyai kemampuan berpikir dan menuangkan ide dalam suatu tulisan atau proposal untuk suatu program acara secara baik dan sistematis, serta mempunyai kemampuan untuk memimpin dan bekerja sama dengan seluruh kerabat kerja dan unsur-unsur produksi terkait; (2) Penulis naskah, seseorang yang pekerjaannya membuat naskah untuk mata acara siaran. Seorang penulis naskah harus memiliki kemampuan menulis naskah drama dan non drama; (3) Pengarah Acara, seseorang yang bertanggung jawab secara teknis pelaksanaan produksi program siaran, pengarah acara bertugas di lapangan untuk mengendalikan produksi yang ditanganinya, oleh karena itu pengarah acara memilki peranan yang sangat strategis dalam sebuah produksi acara televisi; (4) Technical Director (Pengarah Teknik), koordinator keseluruhan kerabat kerja teknik, bertanggung jawab terhadap kualitas video dan audio saat produksi maupun siaran; (5)
Camera Person (Kamerawan), bertanggung jawab untuk pengoperasian kamera televisi selama rehearsal dan produksi program televisi; (6) Editor, orang yang bertugas menyeleksi, memotong, menymbung gambar dan suara sesuai tuntutan naskah; (7) Audio Person (Penata Suara), Penata suara adalah seseorang yang bertanggung jawab terhadap pengoperasian audio atau suara (Hastuti et al., 2020).

Pada publikasi yang dilakukan oleh Supadiyanto, yang berjudul "Implementasi Program Siaran Lokal Pada Stasiun Televisi di Daerah Istimewa Yogyakarta" pada jurnal An-nida, menyimpulkan bahwa implementasi program siaran lokal pada berbagai stasiun televisi yang bersiaran di DIY masih cukup rendah. Karena dari 15 stasiun televisi yang bisa diakses di DIY, baru sebanyak 4 lembaga penyiaran yang menyiarkan program siaran lokal dengan durasi lebih dari 10 persen dari total waktu siaran perhari (Supadiyanto, 2015). Kemudian, pada penelitian yang berjudul "Perencanaan dan Produksi Program Televisi Pendidikan di Televisi Edukasi" oleh Herry Kuswita, menyimpulkan bahwa tahapan proses produksi program pendidikan di Televisi Edukasi, dilakukan sesuai dengan teori yang ada mulai dari saat pra produksi sampai pasca produksi, sehingga program yang ditayangkan benarbenar sudah memenuhi standar program 
televisi layak tayang (Kuswita, 2014). Sedangkan, pada publikasi yang berjudul "Analisis Produksi Program Berita Indonesia Morning Show di News And Entertainment Television" oleh Kemal Aqwam Maulana dan Fatmawati, menyimpulkan bahwa Dalam pelaksanaan produksi program Indonesia Morning Show di NET.TV melalui tiga tahap utama yaitu pra- produksi, produksi dan pascaproduksi yang dimana dalam tahapannya memiliki proses yang berbeda. Kemudian ditinjau dari teori hirarki pengaruh yang berfokus pada level media rutin, dimana dalam pengemasan berita untuk ditayangkan dalam program berita Indonesia Morning Show bahwasannya tim manajerial memilih berita mana yang akan naik dilihat dari unsur audiens sebagai target utamanya. Selanjutnya Analisis yang didapatkan dalam proses produksi program berita Indonesia Morning Show (Maulana \& Fatmawati, 2018).

Atas dasar latar belakang dan referensi yang telah disajikan, penulis tertarik untuk mengkaji implementasi produksi program acara televisi "TEKNOTANI" di LPP TVRI Yogyakarta. Hal inilah yang mendorong peneliti untuk mengetahui lebih mendalam tentang produksi acara televisi TEKNOTANI, sehingga tujuan dari penelitian ini adalah untuk mengetahui proses produksi program TEKNOTANI di LPP TVRI Yogyakarta. Penelitian ini diharapkan menjadi masukan dan rekomendasi kepada pemangku kepentingan dibidang produksi siaran televisi.

\section{Metode Penelitian}

Jenis Penelitian ini adalah penelitian kualitatif dengan metode deskriptif kualitatif, sebagaimana dikemukakan (Sugiyono, 2017) penelitian kualitatif adalah metode penelitian yang dipergunakan untuk meneliti pada kondisi obyek yang alami (natural), peneliti berperan sebagai instrumen kunci dan hasil penelitiannya lebih menekankan pada makna dari yang diteliti daripada generalisasi. Sedangkan obyek penelitian di instansi LPP TVRI Yogyakarta. Adapun subyek dalam penelitian ini dipilih secara purposive, yaitu teknik pengambilan sampel sumber data dengan pertimbangan tertentu (Sugiyono, 2017).

Sumber Data dari penelitian ini meliputi data primer merupakan data yang langsung diperoleh dari pengamatan dan wawancara mendalam dengan para narasumber. Sedangkan data sekunder diperoleh dari hasil dokumentasi dari kantor di LPP TVRI Yogyakarta. Dokumentasi tersebut seperti kearsipan surat, program kegiatan, photo kegiatan dan majalah serta bahan terbitan di LPP TVRI Yogyakarta.

Adapun narasumber dipilih berdasarkan kompetensi dan pengetahuan terkait topik penelitian ini. Selain itu, narasumer 
memiliki jabatan dan wewenang terkait program acara "TEKNOTANI". Oleh karena itu, peneliti menetapkan 4 narasumber yang terdiri dari (1) Budi Silistyo, selaku Kepala Bidang Pemberitaan LPP TVRI Yogyakarta; (2) Riskananta Dewaja, Produser 'TEKNOTANI"; (3) Mutiara, selaku Pengarah Acara LPP TVRI Yogyakarta; dan (4) Tri Wiyanto, selaku Camera Person sekaligus Editor di LPP TVRI Yogyakarta.

Pada teknik pengumpulan data dilakukan secara trianggulasi yang meliputi kegiatan wawancara mendalam, observasi langsung, dan dokumentasi. Dokumentasi adalah setiap bahan yang tertulis atau film, baik yang dipersiapkan untuk penelitian, pengujian suatu peristiwa atau record (Moleong, 2011), maupun yang tidak dipersiapkan untuk itu. Sedangkan teknik wawancara digunakan terutama untuk mengkonstruksi kegiatan dan kejadian di sekitar produksi program TEKNOTANI dari LPP TVRI Yogyakarta. Teknik wawancara yang dipergunakan adalah dengan menggunakan petunjuk umum wawancara (Bungin, 2012), dimana petunjuk wawancara hanya berisi petunjuk secara garis besar tentang proses dan isinya, agar terjaga pokok-pokok dan yang direncanakan dapat tercapai (Moleong, 2011). Teknik yang terakhir adalah observasi sebagaimana dikemukakan oleh
(Patton, 2006) bahwa observasi sistematis dan setepat-tepatnya melibatkan lebih jauh dari hanya sekedar hadir dan melihat-lihat sekitar.

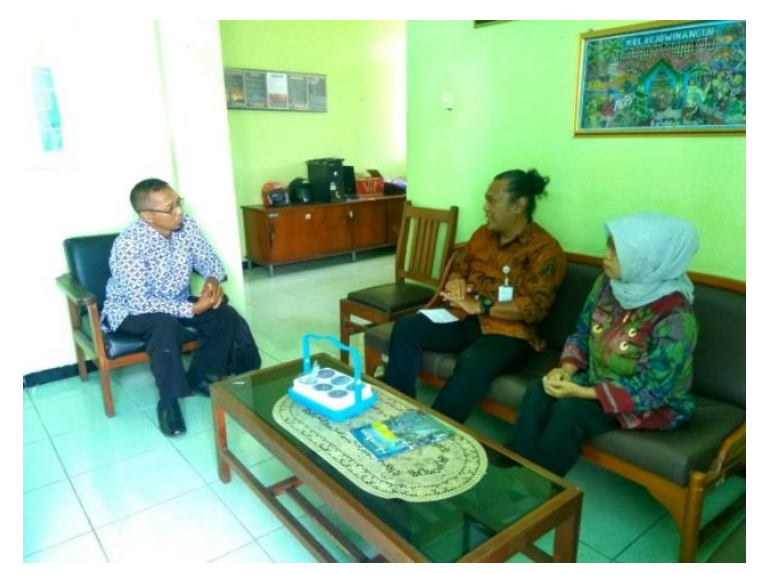

Gambar 1. Kegiatan Wawancara Dengan Narasumber

Untuk menentukan keabsahan data diperlukan teknik pemeriksaan, penelitian ini menggunakan teknik triangulasi. Triangulasi dalam pengujian kredibilitas ini diartikan sebagai pengecekan data dari berbagai sumber dengan berbagai cara dan berbagai waktu. Menurut Susan Stainback dalam (Sugiyono, 2017) menyatakan tujuan dari triangulasi bukan untuk mencari kebenaran tentang beberapa fenomena tetapi bertujuan untuk meningkatkan pemahaman peneliti terhadap hasil temuan dari penelitian.

Teknik pengolahan data dalam penelitian kualitatif dilakukan sejak sebelum memasuki lapangan, selama di lapangan dan setelah di lapangan. Menurut (S. Nasution, 1988) dalam (Sugiyono, 2017) menyatakan "Analisis telah mulai sejak 
merumuskan dan menjelaskan masalah, sebelum terjun ke lapangan, dan berlangsung terus sampai penulisan hasil penelitian. Selanjutnya (Miles \& Huberman, 1992) dalam (Sugiyono, 2017), mengemukakan bahwa aktivitas dalam analisis data kualitatif dilakukan secara interaktif dan berlangsung secara terus menerus sampai tuntas. Aktivitas dalam analisis data, yaitu: data reduction, data display dan conclusions: drawing/verifying.

\section{Hasil dan Pembahasan}

Program TEKNOTANI merupakan program yang diproduksi dan disiarkan secara live delay atau taping, sehingga paket programnya diproduksi terlebih dahulu melalui rekaman atau taping, kemudian baru ditayangkan. Tahapan dalam pembuatan pogram dilakukan melalui 3 tahapan yaitu: Proses PraProduksi, Produksi dan Pasca Produksi.

Tahap
Pra-
Produksi $\Rightarrow \begin{gathered}\text { Tahap } \\ \text { Produksi }\end{gathered} \Rightarrow \begin{gathered}\text { Tahap } \\ \text { Pasca } \\ \text { Produksi }\end{gathered}$

Gambar 2. Proses Produksi TEKNOTANI

1. Tahap Pra-Produksi TEKNOTANI
Proses Pra-Produksi pada pembuatan TEKNOTANI dapat dilihat pada blok diagram berikut.

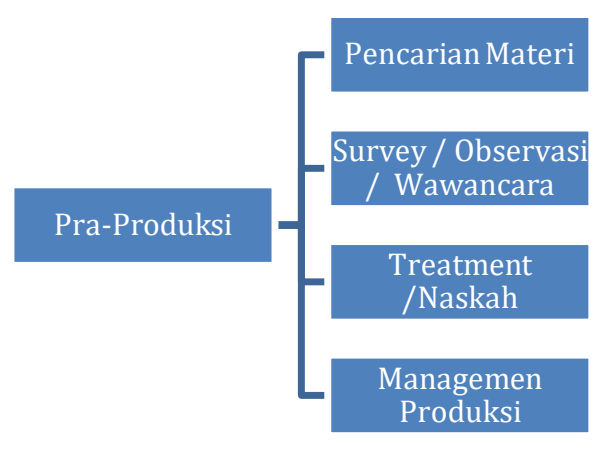

Gambar 3. Proses Pra Produksi

\section{TEKNOTANI}

Dalam Program TEKNOTANI tahap Pra Produksi merupakan tahap yang penting, karena jika tahap ini dilaksanakan dengan rinci dan baik, maka hasil produksinya juga akan lebih baik.

a. Pencarian Materi

Pada tahapan pra-produksi diawali dengan pencarian materi yang dilakukan oleh produser acara. Materi dari program TEKNOTANI dapat berasal dari berbagai sumber, mulai media cetak, elektronik hingga online untuk mendapatkan tema acara berdasarkan isu yang sedang menjadi pembicaraan atau viral di bidang teknologi dan bisnis pertanian. Selain berasal dari media, pencarian materi dan tema program didapatkan dari berbagai pihak yang 
menjadi narasumber pada paket-paket TEKNOTANI sebelumnya.

Setelah mendapatkan beberapa materi, kemudian materi tersebut akan diseleksi untuk mendapatkan tema dan materi yang tepat dan cocok untuk setiap paket program TEKNOTANI yang akan diproduksi. karena dalam setiap bulannya pogram TEKNOTANI disiarkan sebanyak dua kali tayang, yaitu Jumat minggu pertama, kedua dimana setiap tayang temanya berbeda beda. Apabila minggu pertama mengambil tema tentang pertanian, maka minggu ketiga, akan mengambil tema lain misalnya tentang perikanan, sehingga hasil tayangannya selalu bertema variatif. Dalam merancang sebuah bahan materi program, peran produser sangat penting, karena produser lah yang sangat berperan menentukan ide bagi materi tayang.

Pada Program TEKNOTANI edisi Budidaya Tanaman di Lahan Sempit yang rencananya disiarkan tanggal 18 Oktober 2019, menceritakan tentang pemanfaatan lahan sempit untuk ditanami berbagai macam tanaman, di lokasi Kelurahan Rejowinangun, Kecamatan Kotagede, Kota Yogyakarta. Diawali dengan ide produser untuk menampilkan tema tentang pertanian, karena tema sebelumnya tentang peternakan burung tekukur warna. Adapun informasi mengenai budidaya tanaman dilahan sempit didapatkan dari narasumber paket sebelumnya yang memberi tahu tentang adanya daerah perkampungan yang sejuk, karena di setiap gangnya ditanami sayuran, sehingga udaranya segar.

Dalam pemilihan tema tersebut, disamping tema yang dipilih lagi aktual juga ada tujuan dan harapan agar tema yang ditayangkan sesuai dengan misi TVRI serbagai media yang salah satunya memberikan informasi dan juga inovasi kepada masyarakat, dalam hal ini tentang inovasi pertanian. TVRI berharap informasi mengenai pertanian melalui program TEKNOTANI, masyarakat atau pemirsa TVRI dapat memetik manfaatnya.

\section{b. Survey / Observasi / Wawancara}

Tahap selanjutnya pada pra-produksi program acara TEKNOTANI adalah survey lapangan. Pada episode Budidaya Tanaman di Lahan Sempit, survey lapangan dilakukan dua kali. Survey pertama dilakukan untuk menentukan lokasi yang tepat. Kemudian melihat aktivitas dari mayarakat yang akan dilibatkan dalam proses shooting. Pada survey yang kedua, produser sekaligus penulis naskah menentukan narasumber yang akan diwawancarai.

Komposisi untuk narasumber TEKNOTANI memiliki 3 narasumber, 
yaitu narasumber praktisi, narasumber ahli dan narasumber pendukung. Narasumber praktisi dalam hal ini menghadirkan seorang petani yang juga ketua kelompok tani Kelurahan Rejowinangun. Kemudian narasumber kedua adalah seorang tenaga ahli selaku Penyuluh Pertanian Kecamatan Kotagede, Dinas Pertanian Dan Pangan Kota Yogyakarta. Terakhir, Narasumber ketiga adalah narasumber pendukung, dimana narasumber ini tidak harus selalu orang yang terlibat langsung di dunia pertanian, tetapi merpakan narasumber yang mendukung kegiatan itu, dalam hal ini adalah Kepala Kelurahan Rejowinangun, sebagai pemangku gelar dalam mensukseskan program tersebut.

Proses survey lapangan dilakukan pada 3 RW di Kelurahan Rejowinangin. Dimana masing-masing RW memiliki karakteristik dan ciri khas materi yang berbeda. Pada RW 06 ditampilkan footage Landscape lorong sayur, Profil aneka tanaman sayuran, kegiatan penyulaman tanaman, kegiatan penyemprotan hama tanaman, penyiraman tanaman serta panen tanaman sayur sawi dan terong. Sedangkan di RW 08 footage yang akan diambil meliputi landscape dan profil aneka tanaman sayuran dan detailnya, penyiraman tanaman, panen sayuran tomat dan cabai, pengecatan pot dari barang bekas, dan juga profil pot tanaman dari barang bekas dan detailnya. terakhir di RW 12, footage yang akan di shooting meliputi Landscape lorong sempit yang ditanami sayuran dan detailnya, rumah-rumah dengan tanaman sayuran, footage mengenai bagaimana membuat pupuk organik padat dan kegiatan pembibitan serta penyiraman tanaman.

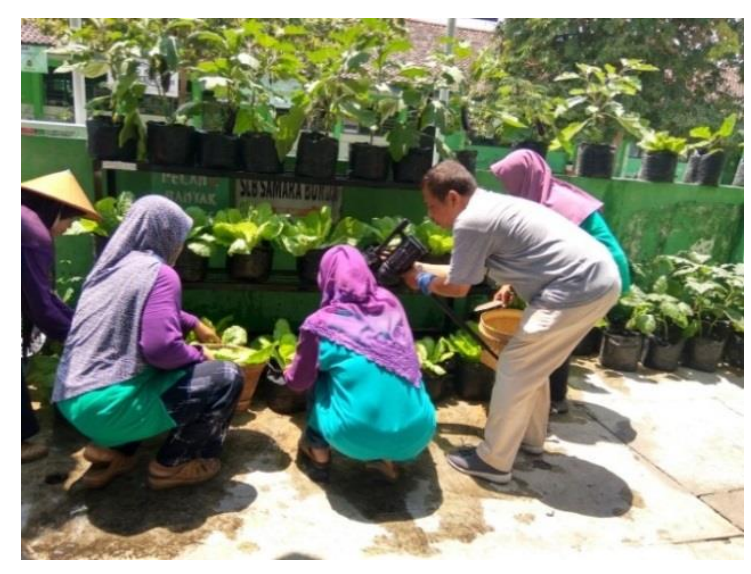

Gambar 4. Proses Pengambilan Gambar Panen Sayuran

Masing masing lahan mempunyai jenis tanaman yang berbeda beda serta masing masing RW mempunyai kegiatan yang berbeda pula. Dengan banyaknya materi yang di-shooting maka akan mempermudah petugas Editor untuk saat melakukan pasca produksi, karena gambar gambarnya bervariasi, sehingga sesuai apa yang menjadi pembicaraan narasumber dapat diberi visual sesuai yang dibicarakan.

\section{c. Treatment dan Naskah}


Treatment adalah kerangka alur cerita program televisi. Pada program TEKNOTANI edisi Budidaya tanaman di lahan sempit, treatment dibuat oleh Produser sekaligus penulis naskah. Jadi treatmentt dibuat sebagai pedoman saat akan melakukan shooting, serta pedoman dalam pembuatan naskah program TEKNOTANI.

Tabel 1. Treatment Program Acara TEKNOTANI

\begin{tabular}{|c|c|}
\hline Parameter & Treatment \\
\hline Siaran & Jumat, 18 Oktober 2019 \\
\hline Visualisasi & Kamis, 03 Oktober 2019 \\
\hline $\begin{array}{l}\text { Rekaman } \\
\text { Studio }\end{array}$ & Selasa, 08 Oktober 2019 \\
\hline Mata Acara & TEKNOTANI \\
\hline Judul & $\begin{array}{l}\text { BUDIDAYA TANAMAN } \\
\text { DI LAHAN SEMPIT }\end{array}$ \\
\hline $\begin{array}{l}\text { Tujuan } \\
\text { Program }\end{array}$ & $\begin{array}{l}\text { 1. Memberikan informasi } \\
\text { dan penerangan tentang } \\
\text { pemanfaatan lahan } \\
\text { sempit untuk pertanian. } \\
\text { 2. Memberikan informasi } \\
\text { dan penerangan tentang } \\
\text { cara melakukan } \\
\text { persiapan budidaya } \\
\text { tanaman sayur untuk } \\
\text { kebutuhan rumah tangga } \\
\text { di lahan sempit. } \\
\text { 3. Memberikan informasi } \\
\text { dan penerangan tentang } \\
\text { teknis budidaya tanaman } \\
\text { sayur di lahan sempit } \\
\text { dari mulai persiapan, } \\
\text { pra-tanam, tanam, panen } \\
\text { sampai pasca panen. } \\
\text { Menggugah masyarakat } \\
\text { untuk melakukan } \\
\text { optimalisasi penggunaan } \\
\text { lahan sempit di area } \\
\text { perkotaan dengan } \\
\text { kegiatan bertani. } \\
\text { Menyampaikan tujuan } \\
\text { optimalisasi lahan sempit }\end{array}$ \\
\hline
\end{tabular}

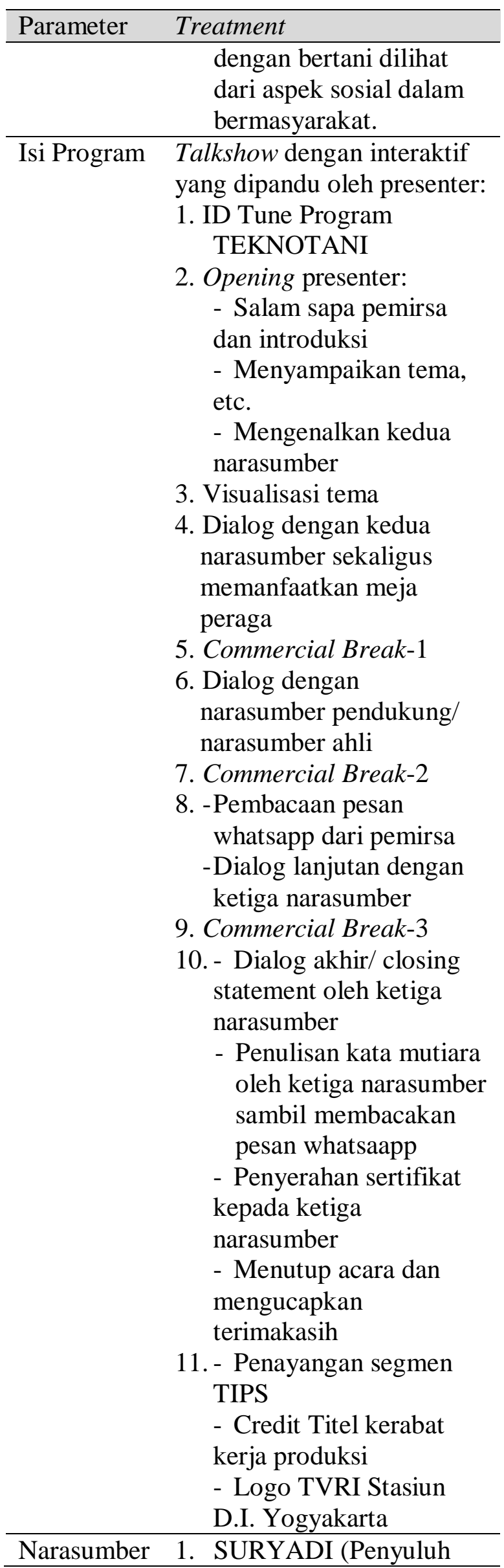




\begin{tabular}{ll}
\hline Parameter & Treatment \\
\hline & Pertanian Lapangan \\
& Kotagede) \\
2. & WULAN \\
& PURWANDARI, S. \\
& STP. (Lurah \\
& Rejowinangun, Kec. \\
& Kotagede) \\
3. & ZUKRI SISWOYO \\
& (Petani) \\
\hline
\end{tabular}

Sumber: TVRI Yogyakarta, 2019

Dari treatment diatas dapat diketahui bahwa tujuan program disesuaikan dengan tema acara. Berhubung tema acaranya tentang pertanian dengan judul Budidaya Tanaman Di Lahan Sempit, maka tujuan programnya juga memberikan informasi dan penerangan tentang pemanfaatan lahan sempit untuk pertanian. Kemudian tentang teknis budidaya tanaman sayur di lahan sempit tersebut mulai dari persiapan, pratanam, tanam, panen sampai pasca panen. Semuanya itu untuk menggugah masyarakat melakukan optimalisasi penggunaan lahan sempit di area perkotaan dengan kegiatan bertani. dilihat dari aspek sosial masyarakat.

Disamping membuat treatmentt, penulis naskah juga membuat pedoman atau konsep melakukan shooting, baik untuk visualisasi atau shooting di lapangan (outdoor), maupun shooting di studio (indoor).

d. Manajemen Produksi
Stasiun televisi adalah tempat kerja yang sangat kompleks, kerena melibatkan banyak orang dengan berbagai jenis keahlian. Suasana kerjanya terkadang penuh ketegangan, khususnya saat menjelang suatu program akan ditayangkan, sehingga diperlukan kesigapan dan kecepatan kerja. Untuk itu komunikasi dan kerjasama yang baik adalah hal yang diperlukan dalam pembuatan produksi program televisi. Membahas jalannya produksi suatu acara televisi, dibutuhkan suatu proses produksi yang terencana dengan baik, sehingga jalannya suatu proses produksi program acara tersebut dapat menghasilkan tayangan yang baik.

Pada tahap manajemen produksi, seorang produser akan menyiapkan berbagai hal tentang kelengkapan sebuah produksi. Diawali dari koordinasi dengan atasan, penentuan jadwal shooting, membuat administrasinya yaitu membuat SOP, kemudian penentuan crew atau kerabat kerja yang terlibat. Serta menyiapkan sarana dan prasarana, dalam hal ini peralatan pendukung shooting.

Proses shooting outdoor program acara TEKNOTANI dilakukan setiap hari kamis dua minggu sekali untuk membuat visualisasi. Kemudian untuk crew yang terlibat di TEKNOTANI ada beberapa orang dengan personal yang berganti-ganti. 
Khusus untuk shooting di lapangan saat pembuatan visualisasi, crew camera person merangkap Editor dilaksanakan oleh satu orang. Sedangkan untuk jabatan pengarah acara dilakukan beberapa orang secara bergantian. Khusus untuk produser dan penulis naskah dijabat oleh satu orang yaitu Riskananta Dewaja.

Dengan komposisi kerabat kerja yang tidak mempunyai Tim Kreatif serta terjadi rangkap jabatan oleh crew karena kekurangan Sumber Daya Manusia, maka akan terjadi kekacauan bila terdapat beberapa crew sedang menangani program produksi yang lain secara bersamaan. Hal ini karena keterbatasan Sumber Daya Manusia di TVRI Yogyakarta, maka masing masing crew atau kerabat kerja tidak hanya menangani satu acara saja, tetapi beberapa acara serta merangkap beberapa jabatan. Akibatnya, terkadang jika terjadi benturan pekerjaan paket program yang lain atau kendala teknis, maka diatasi dengan siaran ulang paket program TEKNOTANI yang telah disiarkan sebelumnya. Sehingga akibat tumpang tindih atau rangkap jabatan dalam pekerjaan, maka dampaknya adalah pemirsa atau penggemar acara tersebut hanya bisa menikmati siaran ulang, atau penayangan paket TEKNOTANI yang telah disiarkan sebelumnya.

\section{Tahap Produksi}

Tahap produksi adalah seluruh kegiatan pengambilan gambar (shooting) baik yang dilakukan di dalam studio (indoor) maupun di luar studio (outdoor). Program TEKNOTANI TVRI Stasiun Yogyakarta adalah sebuah acara yang ditayangkan secara live delay taping, maka proses produksi yang dilakukan adalah melalui beberapa tahapan.

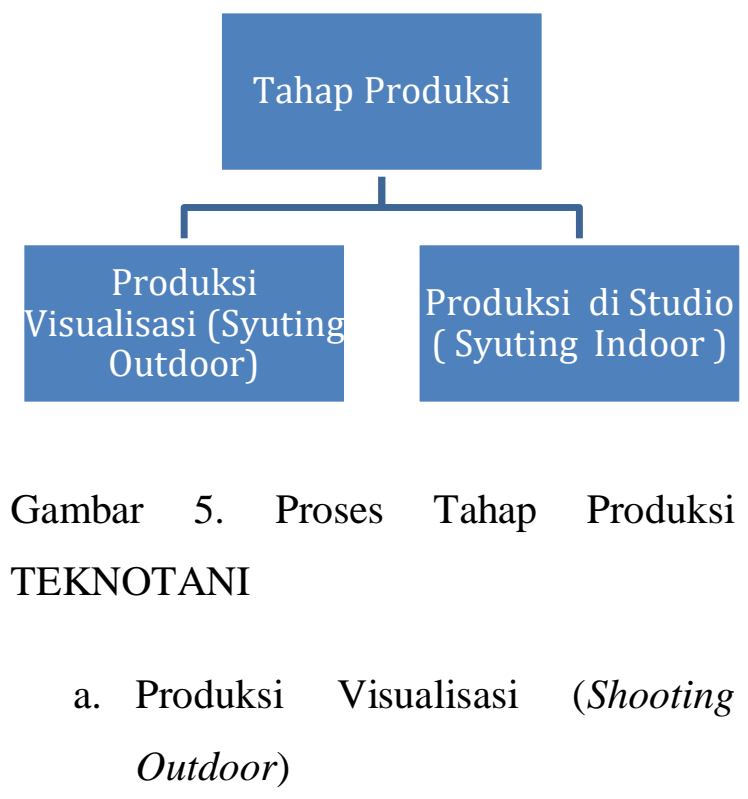

Proses produksi visualisasi merupakan proses produksi di lapangan, dalam hal ini berada di Kalurahan Rejowinangun, Kecamatan Kotagede, Kodya Yogyakarta. Proses Produksi dilakukan sesuai dengan Treatment dan Naskah yang telah dibuat saat Pra Produksi. Pada Program TEKNOTANI episode Budidaya Tanaman di Lahan sempit, maka proses shooting visualisasi dilakukan satu hari dari pagi jam 08.00 WIB hingga petang jam 17.00 WIB. 


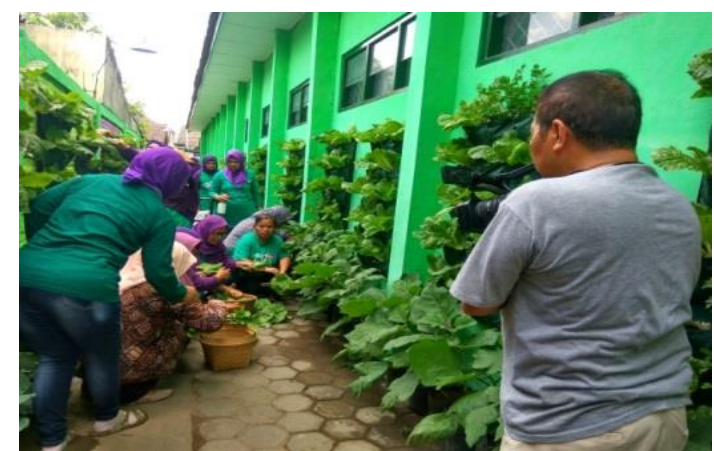

Gambar 6. Proses Pengambilan Gambar

\section{Landscape}

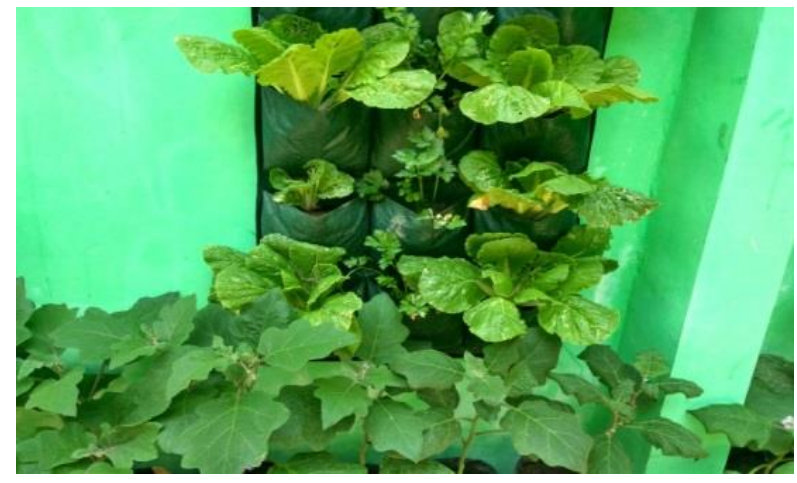

Gambar 7. Proses Pengambilan Gambar

Detail Sayuran Sawi Dan Terong.

Tujuan pengambilan footage ini adalah untuk menunjukkan suasana lorong yang penuh dengan tanaman sehingga suasana menjadi sejuk dan udaranya juga segar, serta pengambilan berbagai detail dari tanaman.

\section{b. Shooting di Studio (Indoor)}

Shooting di studio dilaksanakan sesuai jadwal yang telah ditentukan, sehingga ketika produksi acara di studio telah dipersiapkan secara matang, karena melibatkan banyak kerabat kerja. Bila ada kesalahan sedikit saja baik teknis maupun non teknis dapat menghasilkan produk tayangan yang kurang baik, sehingga dapat mengurangi kualitas tayangan dan hasilnya tidak maksimal. Pada tahap ini segala ide yang telah dituangkan ke dalam kertas rundown acara pada tahap pra produksi diubah menjadi bentuk konkret.

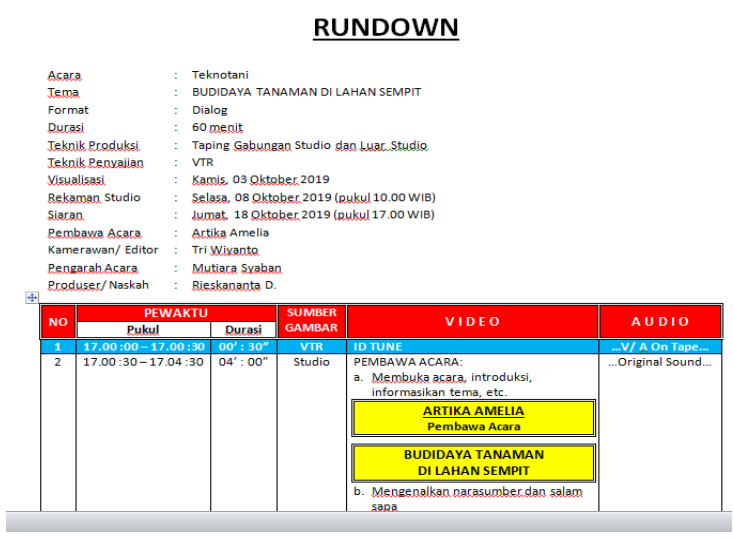

Gambar 8. Rundown acara TEKNOTANI

(Sumber: TVRI Yogyakarta, 2019)

Rundown acara merupakan urutan kegiatan atau urutan segmen yang akan diproduksi. Pada episode Budidaya Tanaman di Lahan Sempit, terlihat bahwa awal segmen berupa tune acara TEKNOTANI dengan durasi 50 detik. Segmen selanjutnya adalah pembawa acara atau host, dalam hal ini dipandu oleh Artika Amelia membuka acara dengan memperkenalkan tema acara TEKNOTANI, yaitu Budidaya Tanaman di Lahan Sempit. Artika Amelia juga mengenalkan ke tiga narasumber dan salam sapa kepada narasumber dan pemirsa. 


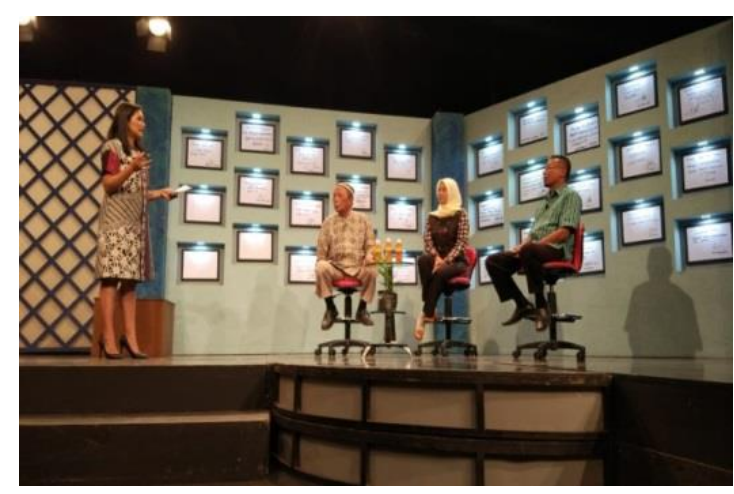

Gambar 9. Suasana di Studio Saat Produksi Indoor

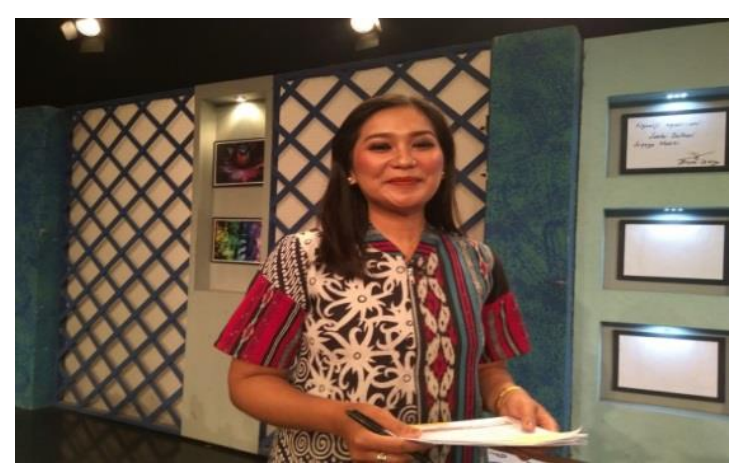

Gambar 10. Presenter memandu acara TEKNOTANI

Gambar 9, menampilkan suasana di studio saat rekaman atau produksi indoor. Gambar 10. Presenter memandu jalannya acara selama satu jam kedepan. Presenter membuka acara kemudian menjelaskan tema apa yang akan diangkat, yaitu budidaya tanaman di lahan sempit. Disini terlihat bahwa ada 3 narasumber dan seorang pembawa acara di studio.

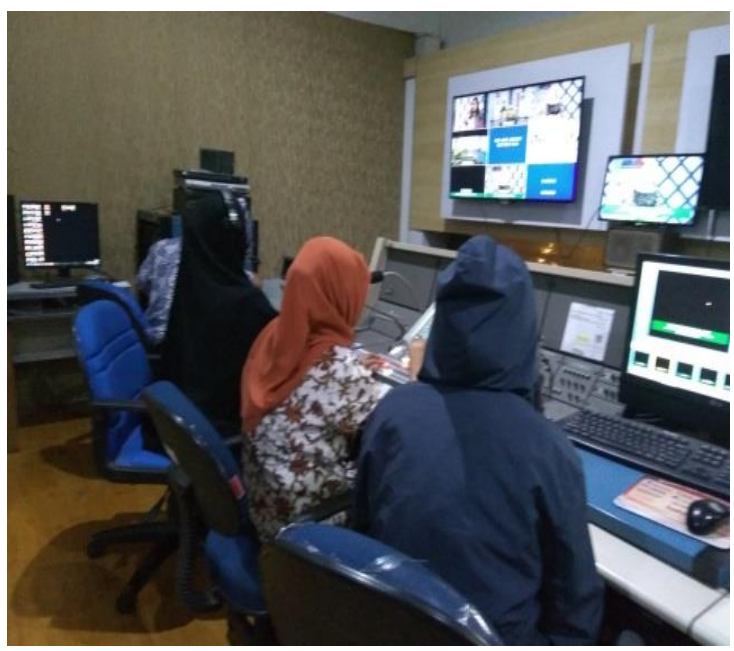

Gambar 11. Crew di Ruang Master

\section{Control}

Gambar 11 dan Gambar 12, memperlihatkan bahwa saat shooting di studio, kerabat kerja yang terlibat lebih banyak. Mulai dari pengarah acara, Switcher, penata suara, penata cahaya, kemudian penata kamera, asisten pengarah acara (floor director) dan masih banyak lagi. Saat proses produksi di studio inilah faktor komunikasi sangat diperlukan, karena saat shooting membutuhkkan koordinasi antar kerabat kerja yang letaknya beda tempat. Untuk itulah konsep saat pra-produksi harus lebih teliti, sehingga mempermudah saat proses produksi. 


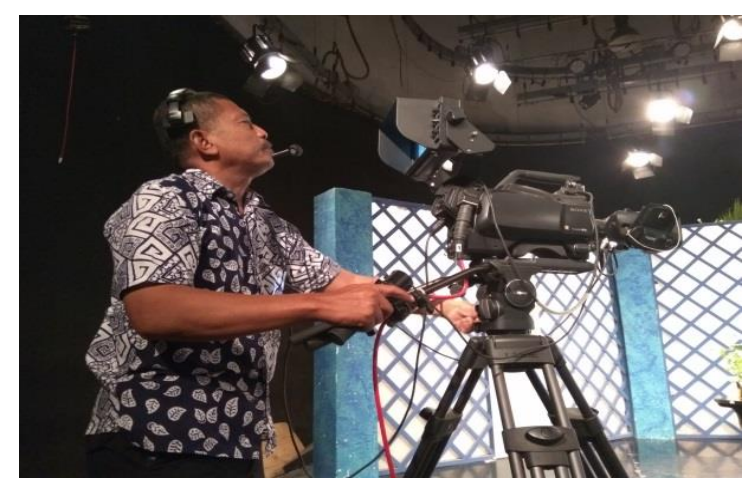

Gambar 12. Camera Person Ketika

Shooting Indoor TEKNOTANI

3. Tahap Pasca Produksi

Tahapan terakhir dalam melaksanakan proses produksi, yaitu tahap pasca produksi. Tahapan pasca produksi merupakan suatu kerja pada tahapan terakhir dari bahan yang telah diproduksi. Tahapan pasca produksi meliputi penyutingan atau editing gambar dan suara, pengisian grafik, baik berbentuk tulisan maupun berbentu foto-foto, dan pengisian narasi serta pencarian ilustrasi.

Langkah-langkah yang dilakukan pada tahapan editing diantaranya adalah proses editing offline, dimana Editor akan memilih dan menyambung gambar secara kasar sesuai tuntutan naskah. Kemudian, editing online yaitu penyuntingan gambar secara halus atau tepat. Sambungansambungan setiap shoot dan adegan dibuat tepat berdasarkan tuntutan naskah.

Editing yang dilakukan pada program TEKNOTANI edisi Budidaya Tanaman di
Lahan Sempit dilakukan untuk membuat visualisasi. Jadi materi yang diedit hanya hasil syuring di lapangan sebagai bahan visualisasi. Saat membuat materi visualisasi, didalamnya sudah termasuk segmen yang berisi visual dan narasi. Editing dilakukan tanpa pendamping Pengarah Acara, dikarenakan masing masing crew mempunyai kesibukan yang berbeda-beda. Masing-masing crew biasanya juga merangkap tanggung jawab pada program acara lain.

4. Evaluasi Proses Produksi Program Acara TEKNOTANI

Pelaksanaan tahapan produksi program acara TEKNOTANI di LPP TVRI berjalan dengan baik dan sesuai dengan kaidah penyiaran yang benar. Setiap crew menjalankan tugasnya dan baik serta semua pihak mendukung terlaksananya proses shooting baik di outdoor maupun indoor. Demikian juga dengan pemilihan tema dan materi, telah sesuai dengan ekspektasi dan target pemirsa serta mampu memberikan informasi yang berguna terutama bagi penggiat pertanian di Yogyakarta

Walaupun demikian terdapat beberapa hal yang perlu di evaluasi dalam pelaksanaannya terutama dalam hal pengaturan tugas personil produksi acara. Karena banyak personil yang mengemban 
tugas lebih dari satu pekerjaan serta lebih dari satu program acara secara bersamaan. Sehingga dengan beban kerja yang besar menimbulkan stress bagi masing-masing personil. Selain itu, pengentahuan produser akan dunia pertanian tidak mendalam. Hal ini mempengaruhi kualitas acara yang disajikan dan informasi serta pesan tidak secara optimal tersampaikan kepada pemirsa.

Oleh karena itu, perlu adanya pengurangan beban kerja dan pengaturan tugas yang lebih baik. Salah satu solusinya adalah memberikan pelatihan atau sertifikasi bagi personil lain yang belum memiliki kompetensi di bidang produksi seperti penulisan naskah atau pengarah acara. Sehingga mampu mengisi posisi yang dibebankan oleh personil lain yang memiliki beban lebih.

\section{Kesimpulan dan Saran}

\subsection{Kesimpulan}

Dalam proses produksi program TEKNOTANI edisi Budidaya Tanaman di Lahan Sempit dengan lokasi Kalurahan Rejowinangun, Kecamatan Kotagede, Kodya Yogyakarta, maka proses produksinya melalui beberapa tahapan yaitu pra-produksi, produksi dan pasca produksi. Pada tahapan pra-produksi, Diawali dengan pencarian materi melalui beberapa cara, yaitu melalui media, baik media cetak maupun media elektronik, lewat internet dan juga melalui jaringan informasi dari narasumber paket TEKNOTANI episode sebelumnya. Setelah materi didapat dilanjutkan dengan survey lapangan untuk menentukan kepastian lahan yang tepat sebagai visual serta kepastian narasumber. Setelah melakukan survey, observasi dan wawancara dilanjut dengan pembuatan Treatment dan naskah sebagai pedoman untuk produksi baik untuk shooting di lapangan (outdoor) dan shooting di Studio (indoor). Produser membuat manajemen Produksi dengan melakukan koordinasi dengan atasan, untuk membuat jadwal shooting, menyelesaikan administrasi seperti pembuatan SOP yang berisi pedoman shooting, pembuatan rundown acara serta menentukan nama kerabat kerja yang terlibat. Proses Produksi merupakan proes kelanjutan dari proses Pra Produksi berupa pelaksanaan shooting. Dalam hal ini shooting dilakukan dengan dua kegiatan yaitu shooting visualisai di lapangan atau (outdoor) shooting visualisasi digunakan sebagai insert gambar pada saat narasumber menjelaskan sesuatu. Sedangkan, produksi indoor atau produksi di studio dilakukan dengan mengundang tiga narasumber. Proses pasca produksi merupakan tahapan terakhir dalam melaksanakan proses produksi. Kegiatan yang dilakukan pada proses pasca produksi meliputi editing offline 
yang dilanjutkan dengan editing online. Dalam tahap pasca produksi ini pengisian narasi untuk segmen visualisasi dilakukan.

\subsection{Saran}

1. Dalam produksi program TEKNOTANI dapat memberikan interaksi terhadap pemirsa secara langsung seperti panggilan telpon pemirsa sehingga dapat memberikan kesan yang yang dekat terhadap masyarakat.

2. Dalam ketersinambungan penelitian yang berkala, dapat dikaji seberapa jauh manfaat program teknotani jika dilihat dari sudut pandang masyarakat terutama petani.

3. Penelitian pada program acara TEKNOTANI dapat dikaji dari sisi editing, audio, juga komposisi gambar yang digunakan.

\section{Referensi}

Afifi, S. (2010). Tayangan Bermasalah Dalam Program Acara Televisi Di Indonesia. Jurnal Ilmu Komunikasi UPNYK, 8(3), 101130.

Arifin, Y., Ricky, M. Y., \& Yesmaya, V. (2015). DIGITAL MULTIMEDIA (Ariyanto (ed.)). Bina Nusantara. Bungin, B. (2012). Penelitian Kualitatif: Komunikasi, Ekonomi, Kebijakan Publik, dan Ilmu Sosial Lainnya. Kencana.
Fahruddin, A., \& Asy'ari, N. A. S. (2019). Kajian Teori Strategi Programming Sydney W. Head pada Program Acara Dakwah ADiTV. ProTVF, 3(1), 1. https://doi.org/10.24198/ptvf.v3i1.212 07

Hastuti, S., Purwanto, P., \& Wahyudin, A. (2020). Implementasi Teknik Penyutradaraan Acara Ketoprak di RRI Purwokerto. Komunika Jurnal, $9(1)$.

https://doi.org/10.31504/komunika.v9 i1.3225

Kurniawati, L. (2019). Implikasi standar program siaran pada tayangan edukasi dan artistik TVRI Jawa Barat.

ProTVF, 3(2), 141.

https://doi.org/10.24198/ptvf.v3i2.230 08

Kustanto, L. (2016). Analisis Naratif: Kemiskinan Dalam Program Reality Tv "Pemberian Misterius" Di Stasiun SCTV. REKAM: Jurnal Fotografi, Televisi, Dan Animasi, 11(2), 109. https://doi.org/10.24821/rekam.v11i2. 1297

Kuswita, H. (2014). PERENCANAAN

DAN PRODUKSI PROGRAM TELEVISI PENDIDIKAN DI TELEVISI EDUKASI Herry. Jurnal Komunikologi, 11(2).

Latief, R., \& Utud, Y. (2017). Menjadi produser televisi : Profesional mendesain program televisi. 
Prenadamedia Group.

Luthfi, A. (2018). Pendidikan Seni Film dan Televisi Menjadi Penggerak Industri Ekonomi Kreatif. REKAM: Jurnal Fotografi, Televisi, Dan Animasi, 13(2), 99. https://doi.org/10.24821/rekam.v13i2. 1933

Maulana, K. A., \& Fatmawati, F. (2018). Analisis Produksi Program Berita Indonesia Morning Show di News and Entertainment Television. Profetik: Jurnal Komunikasi, 11(2), 58.

https://doi.org/10.14421/pjk.v11i2.14 23

Miles, M. B., \& Huberman, M. (1992). Analisis Data Kualitatif Buku Sumber Tentang Metode-metode Baru. UIP.

Moleong, L. J. (2011). Metodologi Penelitian Kualitatif Edisi Revisi. Remaja Rosdakarya.

Morissan. (2008). Manajemen Media Penyiaran: Strategi Mengelola Radio \& Televisi. Kencana Prenada.

Nasution, N. (2018). Strategi Manajemen Penyiaran Radio Swasta Kiss Fm Dalam Menghadapi Persaingan Informasi Digital. 2(2), 145-156.

Nasution, S. (1988). Metode Penelitian Naturalistik Kualitatif. Tarsito.

Patton, M. Q. (2006). Metode Evaluasi Kualitatif. Pustaka Pelajar.

Purwanto, Lestari, P., \& Wahyudin, A.
(2019). Evaluasi Pelaksanaan

Digitalisasi Penyiaran Di LPP TVRI

Stasiun Jakarta. Jurnal Heritage, 7(2).

https://doi.org/https://doi.org/10.3589

1/heritage.v7i2.1797

Raharjo, A., \& Anisti. (2018). Peran

Program Director Tv Dalam Proses

Produksi Visual Program Acara

Semesta Bertilawah Di MNC TV.

Jurnal Komunikasi, 9(1).

Subroto, D. S. (1994). Produksi Acara

Televisi. Duta Wacana University

Press.

Sugiyono. (2017). Metode Penelitian

Kuantitatif Kualitatif dan $R \& D$.

Alfabeta.

Sunarsa, S., Wahyudin, A., \& Suparno, B.

A. (2020). STRATEGI KEBIJAKAN

PENYIARAN LEMBAGA

PENYIARAN PUBLIK LOKAL

RADIO IN FM KEBUMEN. Jurnal

Heritage, 8(1), 114-126.

https://doi.org/https://doi.org/10.3589

1/heritage.v8i2.1924

Supadiyanto. (2015). Implementasi

Program Siaran Lokal Pada Stasiun

Televisi Di Daerah Istimewa

Yogyakarta. Jurnal An-Nida, 7(2).

Wibowo, F. (2007). Teknik Produksi

Program Televisi. Pinus.

Wulandari, Y., \& Wahyudin, A. (2020).

STRATEGI PENINGKATAN

KOMPETENSI PENGARAH

ACARA TVRI JAWA BARAT 
SESUAI SKKNI. REKAM: Jurnal

Fotografi, Televisi, Animasi, 16(1),

45-53.

https://doi.org/10.24821/REKAM.V1

611.3585

Yogyakarta, B. P. S. D. . (2020). Provinsi

Daerah Istimewa Yogyakarta Dalam

Angka 2020. In Badan Pusat Statistik

Propinsi D.I Yogyakarta. Badan Pusat

Statistik Propinsi D.I Yogyakarta. 